\title{
Recontextualizing Scandinavian Practices in a Latin American Regional Office
}

\author{
Ramirez, Jacobo; Søderberg, Anne-Marie
}

\author{
Document Version \\ Accepted author manuscript \\ Published in: \\ Management Research: the journal of the Iberoamerican Academy of Management
}

DOI:

10.1108/MRJIAM-12-2018-0895

Publication date:

2020

License

Unspecified

Citation for published version (APA):

Ramirez, J., \& Søderberg, A-M. (2020). Recontextualizing Scandinavian Practices in a Latin American Regional Office. Management Research: the journal of the Iberoamerican Academy of Management, 18(1), 99-119. https://doi.org/10.1108/MRJIAM-12-2018-0895

Link to publication in CBS Research Portal

\section{General rights}

Copyright and moral rights for the publications made accessible in the public portal are retained by the authors and/or other copyright owners and it is a condition of accessing publications that users recognise and abide by the legal requirements associated with these rights.

\section{Take down policy}

If you believe that this document breaches copyright please contact us (research.lib@cbs.dk) providing details, and we will remove access to the work immediately and investigate your claim. 


\title{
Recontextualizing Scandinavian Practices in a Latin American Regional Office
}

\author{
Jacobo Ramirez and Anne-Marie Sederberg
}

Journal article (Accepted manuscript*)

\section{Please cite this article as:}

Ramirez, J., \& Søderberg, A-M. (2019). Recontextualizing Scandinavian Practices in a Latin American Regional Office. Management Research: the journal of the Iberoamerican Academy of Management, 18(1), 99-119. https://doi.org/10.1108/MRJIAM-12-2018-0895

\section{DOI: 10.1108/MRJIAM-12-2018-0895}

This article is [C Emerald Group Publishing and permission has been granted for this version to appear here: https://research.cbs.dk/en/publications/recontextualizing-scandinavian-practices-in-a-latin-american-regi. Emerald does not grant permission for this article to be further copied/distributed or hosted elsewhere without the express permission from Emerald Group Publishing Limited.

* This version of the article has been accepted for publication and undergone full peer review but has not been through the copyediting, typesetting, pagination and proofreading process, which may

lead to differences between this version and the publisher's final version AKA Version of Record. 


\title{
Recontextualizing Scandinavian practices in a Latin American regional office
}

\begin{abstract}
Purpose: The aim of this study was to explore how Danish and Mexican communication and management practices are recontextualized at the Latin American office of a Scandinavian multinational corporation (MNC) located in Mexico.
\end{abstract}

Design/methodology/approach: A case study based on interviews, observations and company documents was conducted.

Findings: Well-educated Mexican middle managers appreciate the participative communication and management practices of Scandinavian MNCs, which transcend most experiences at local workplaces, but their interpretations and meaning system are influenced by the colonial legacy and political and socioeconomic context framing their working conditions.

Originality/value: This article provides a contextualized analysis of a rich case study to further illustrate the challenges faced by MNCs in their quest to establish a regional office in a Latin American context and offers a theoretical model of the elements involved in complex recontextualization processes.

Key words: recontextualization, intercultural communication, Denmark, Mexico

Article classification: Case Study 


\section{Introduction}

The transfer of practices from the headquarters (HQs) of a multinational corporation (MNC) to its regional offices requires a balance between global integration and local responsiveness (Roth and Morrison, 1990), and MNCs must make a strategic choice between integrating operations at a global level or ensuring responsiveness through local adaptation. Within this integration-responsiveness (I-R) framework, some international business (IB) scholars have argued that some levels of translation, recontextualization (Brannen, 2004), and local adaptation (Ansari et al., 2014) of HQ practices are needed to ensure alignment with the local context and benefit from local expertise. However, IB scholars also argue that to achieve global competitiveness, certain practices should be standardized and implemented at each regional office of an MNC (Perlmutter, 1969). Standardization is typically related to technical processes, but it is sometimes argued that MNCs should transfer their HQ's "best practices" to all their business units worldwide (Schmid, 2018). The management practices established at an MNC's HQ typically signal the corporate values (Newburry et al., 2014) that the MNC might aim to standardize across regional offices worldwide. However, a gap exists in our understanding of how local managers and employees make sense of these so-called transfers of practices from abroad, and the extent to which these practices take on new meanings to fit the local context and adapt to the current communication and management practices in the host country is unclear.

The purpose of our case study of a Scandinavian MNC regional office in Latin America is to shed light on intercultural communication and management processes that facilitate team and organizational performance in this specific IB context. We analyzed the empirical material to answer the following research questions: 
- Are Scandinavian communication and management practices adapted to local traditions and needs through dialogue between Danish and Mexican managers?

- Are the corporate values of Scandinavian MNCs adapted to the local context?

We study intercultural communication and management processes as social interaction and reinterpretation in a specific sociocultural and organizational context. This approach has implications for our choice of focusing our analysis on how Danish and Mexican staff members in a regional office develop a dialogue that could be considered a common ground (Nardon et al., 2011) on which their daily cross-cultural collaboration relies. We studied a regional office of Arla Foods, which is a Scandinavia-based MNC, in Mexico. Our findings reveal how Danish managers who are familiar with Scandinavian participative leadership succeed in recruiting welleducated and internationally experienced Mexican middle managers who are socialized in the context of traditional Mexican paternalistic leadership to a certain extent and attracted by an empowering management approach. These well-educated Mexican middle managers appreciate the participative communication and management practices that transcend their experiences at most local workplaces, but their local meaning systems are influenced by the colonial legacy and political and socioeconomic context framing their working conditions in Mexico. Our findings further illustrate that corporate Arla Foods values are not subject to negotiation or recontextualization at its regional office in Mexico, which is discussed in the international management literature as an ethnocentric approach (Perlmutter, 1969; Schmid, 2018).

Our case study illustrates the challenges faced by MNCs in their quest to establish regional offices in a Latin American context. We highlight issues related to the frameworks of global standardization and the local adaptation frameworks widely used in the IB literature and 
practitioners in MNCs. Our case study contributed to the IB literature by proposing a model titled Recontextualization of Communication and Management Practices in a Foreign Regional Office of an MNC. We acknowledge that the Latin American region has specific features that have shaped the business culture in the region (Lenartowicz and Johnson, 2002). The Latin American region shares common features (cultural traits) but has a different history and legacy (e.g., military regimes, languages, including indigenous languages, etc.), and such specific aspects are beyond the scope of this case study. However, in our model, we posit that the legacy of the political and socioeconomic conditions found in the region along with other features impact local managers in foreign subsidiary negotiating and recontextualizing with expatriates communication and management practices. Our model can help replicate our findings in other Latin American countries.

An implication of our case for practitioners and MNCs is that expatriated managers must have an understanding of the host country's history, current development, language proficiency and cultural sensitivity to span the boundaries between the HQ and affiliates in their efforts to drive successful translation, negotiation and recontextualization processes in collaboration with local managers and employees.

The remainder of this paper is structured as follows. First, we present the theoretical framework. Second, we introduce the research context of our case study. Third, the methods used to collect and analyze the empirical material are presented. Finally, we discuss the findings, propose the theoretical model emerging from our case analysis and highlight the managerial implications. 


\section{Theoretical perspectives}

\section{Global integration and local responsiveness}

For decades, the international management literature has been occupied with an important debate concerning global integration vs. local responsiveness. The I-R framework has been used in seminal texts by Prahalad and Doz (1987), Bartlett and Ghoshal (1989), and Roth and Morrison (1990) to characterize the strategic choices of MNCs between either integrating operations at a global level to achieve efficiency through scale and scope or ensuring responsiveness through adaptation to local conditions in foreign subsidiaries. One instance in which local adaptation is observed is the recruitment and selection of host-country employees to devise and implement sales and distribution strategies for specific products that are in high demand on the local market.

International management scholars frequently refer to "standardization" vs. "localization" when discussing how MNCs regard preferred practices at their HQ and foreign subsidiaries, such as within human resource management (HRM). With perceived pressures for both global integration and local responsiveness, a company may decide to develop and seek to implement what it considers "best practices" in all business units worldwide or it may be convinced of the importance of developing a specific approach to certain issues. In particular, HRM issues, including recruitment, promotion criteria, employee incentives, and superior-subordinate relationships, can be crucial for attracting and retaining the most qualified employees. IB scholars acknowledge that the "blind application" of management practices (such as regioncentric practices) among MNCs in Latin America (Newburry et al., 2014) may prove challenging in the heterogeneous Latin America context. 
However, while it is common to analyze the strategies developed by top management at HQ and their preferred communication and management practices, it is uncommon to study how a specific company strategy is employed in a foreign subsidiary or a regional office and investigate the consequences of transferring practices from HQ to new sociocultural contexts. Therefore, we introduce a supplementary theoretical perspective that challenges the widespread concept of the transfer of practices from one context to another.

\section{Transfer of knowledge and practices}

The concept of transfer is frequently used in international management discourse. We encounter 'transfer of knowledge' across national and regional boundaries within MNCs (e.g., Kogut and Zander, 2003) and cross-national 'transfer of organizational practices' from HQ to foreign subsidiaries in the seminal IB literature (e.g., Kostova and Roth, 2002). Nevertheless, we

find the use of the concept of transfer in IB studies problematic since it assumes a unidirectional and seamless transmission of knowledge, technologies and practices from the powerful HQ to the less powerful foreign subsidiaries that are conceived merely as recipients of knowledge regarding corporate values, technologies or best practices. However, Frenkel (2008) encourages IB scholars to rethink the concept of 'transfer' in international management discourse regarding cross-cultural interactions in MNCs and reflect on the assumptions embedded in the widely used concepts of 'transfer of knowledge' and 'transfer of practices'. Her analysis of the cross-national transfer of knowledge and practices within MNCs shows how knowledge and practices are "not neutral instruments that merely represent reality or signify the best or most efficient mode of conduct" (op.cit. p. 926) and, therefore, simply need to be 'implemented' in another sociocultural setting. She promotes an alternative understanding of the process by claiming that 
knowledge, values, technologies, and strategic practices should all be understood as systems of classification that both represent and reproduce social hierarchies of the powerful Western HQ and the less powerful foreign subsidiaries that are dominated and forced to 'develop' to meet the standard set by the HQ. Thus, the transferred knowledge, values, technologies and practices may have so-called 'performative power' as they may reshape certain characteristics (technological, economic, political, and cultural) of the 'receiving' society (Meyer, 2002).

Consistent with Frenkel (2008), we prefer to think in terms of a dialogue between the HQ and foreign subsidiaries and among the expatriate managers, local managers and employees in a given foreign subsidiary or regional office. We consider expatriates individuals actively engaged in sense-giving (Gioia and Chittipeddi, 1991) by re-interpreting HQ values and practices. This approach offers individuals opportunities to negotiate and even resist imposed values and practices that do not fit the specific local framework of meaning and, thus, do not make sense to them and/or match the socio-economic conditions in the specific local business context (Liker et al., 1999). Below, we provide a brief overview of how organizational scholars address the travel of ideas, objects and practices in a globalized world.

\section{Practices travel: a semiotic approach to recontextualization}

Czarniawska and Sevón (1996) challenged the widespread models of 'planned' and 'determined' organizational change. These authors explore how ideas and models of organization evolve and travel both locally and globally and focus on the conditions that may foster or impede transferability. Czarniawska and Sevón (2005) strengthen their focus on how selected ideas, objects and practices travel in the global economy and become global ideas when enacted in new contexts. 
Drawing upon semiotics, Brannen (2004) used the concept of recontextualization with reference to the shift in meaning that occurs when a sign is 'sent' and then acquires a different meaning when it is 'received' and interpreted by people with another local system of meanings. Thus, recontextualization is "the phenomenon whereby taking a concept or practice across borders leads to either the practice or its meaning changing" (op.cit.: 604). According to Moore (2015), values and meanings are particularly subject to change through the recontextualization process, which involves a constant negotiation of meanings. Both the 'sender' and 'receiver' in intercultural communication are actively involved in reinterpretation processes and enable recontextualizations (Moore, 2015). Thus, recontextualization stresses the importance of the legacy of the political and sociocultural contexts in which some practices are transformed, whereas other practices continue.

The recontextualization concept is also highly relevant to studies investigating corporate values and preferred behaviors in global organizations because it allows scholars to track shifts in the meanings attached to them as they travel from the HQ context to a different sociocultural environment. For example, at regional offices, expatriate managers attempt to make sense of MNC corporate values and preferred practices for their employees, and local employees attempt to make sense of such values and practices in their daily working lives. Søderberg (2015) investigated how a strategic concept developed based on the initiative of top management at a Danish MNC to improve global integration in a multinational organization was recontextualized. Her case study draws upon interviews, observations and documents collected at the company headquarters in Denmark and its subsidiaries in China and Malaysia. At the foreign subsidiaries, the expatriate and local managers played important roles as change agents as they attempted to give sense to the preferred behaviors in various manners. However, the local employees, who 
presented their own communication and leadership ideas as they attempted to make sense of and transform the MNC's preferred behaviors into sustainable practices, were equally important (Søderberg, 2015).

We acknowledge that HQ strategies and local conditions shape the transformed communication and management practices at a given regional office. These arguments are presented in the following section.

\section{Transformation of practices and cultural continuity}

Some ethnographic studies (d'Iribarne, 2012; Yousfi, 2014) are concerned with how Western MNCs from 'developed countries' can succeed in managing in synergy with local frameworks of meaning and local visions of the right way to achieve a good life that exist in various 'developing countries'. Yousfi (2014) focuses on the import of Western management practices in a Tunisian company with a strong colonial heritage. She argues that a national culture, which is understood as a local framework of meaning regarding acceptable ways of organizing and regulating social life, may shape the way local managers resist, embrace, adopt or adjust to imported practices. Yousfi's (2014) study identifies both the practices that are transformed as local workers negotiate and reinterpret Western management practices via a local cultural framework of meaning and the practices that persist due to the workers' resistance to reinterpretation and recontextualization.

Based on case studies in Mexico and other developing countries, d'Iribarne (2002) and d'Iribarne and Henry (2007) argue that although national and organizational cultures change over time, certain forms of cultural continuity can persist as reference points or a framework of meaning that guides organizational actors (e.g., employers and employees) belonging to a 
specific community in their interpretations, thereby providing 'acceptable ways of organizing and regulating social life' (d'Iribarne and Henry, 2007). Within this understanding of cultural communities, people can share several cultural references even if they use them differently because they are socialized within the same sociocultural context.

In the analysis of our case study, we explore how such representations may give meaning to people's experiences at work, people's conceptualization of 'acceptable' ways of communicating, managing and working together; and people's knowledge of activities that should not be performed in the workplace. We treat these behavioral patterns as local frameworks of meaning that allow highly diverse types of actions and even competing interpretations among members of a cultural community.

\section{Materials and methods}

In this section, we first present the case company and the research context of our case study in more detail and then present our methodological choices.

\section{Research context}

A case study of Arla Foods and one of its regional offices

Arla Foods was created in 2000 as a result of a merger between MD Foods of Denmark and Arla of Sweden. Arla Foods is a Scandinavia-based MNC owned by 10,319 farmers (Arla Foods, 2018). Over time, Arla Foods has developed a legacy in terms of ownership and democratically managed cooperatives that has become increasingly attractive and expanded from a local level to regional and eventually national levels (Arla Foods, 2014). According to Arla 
Foods, one goal of the cooperative system is to ensure prompt communication and transparency to improve dialogue across the MNC and ensure open communication regarding Arla Foods' activities and its impacts on local communities (Arla Foods, 2016).

The cooperative system is reflected in Arla Foods' corporate values, which are based on what Arla Foods considers its Character as follows: lead, sense and create (Arla Foods, 2019). Lead refers to "being passionate, striving for leadership and identifying the highest potential in our people, business and relationships" (Arla Foods, 2019). Sense refers to "showing integrity, having an open mind, seeing opportunities and high potential in our people, business and relationships". Create refers to "creating and developing strong potential in our people, business and partnerships" (Arla Foods, 2019). Arla Foods has a global policy that all white-collar employees must be trained in Arla Foods' Code of Conduct, which is based on the firm's corporate values. Training is conducted by policy awareness using an e-learning platform (Arla Foods, 2018).

Arla Foods is the largest organic dairy producer worldwide and has the second largest milk pool in Europe (Arla Foods, 2018). In 2018, Arla Foods had a revenue of 10.4 billion euros (Arla Foods, 2018). Regarding sales and brand value, Arla Foods is the $7^{\text {th }}$ largest dairy company worldwide following Nestlé, Lactalis, Danone, Dairy Farmers of America, Fronterra, and FrieslandCampina (Marketing91, 2018; Rabobank, 2018). In 2018, Arla Foods had 19,190 employees in 105 countries concentrated in Northern Europe, North America, the Middle East, North Africa, China, Southeast Asia and Sub-Saharan Africa (Arla Foods, 2018).

Arla Foods first expanded within the European Union and then decided to establish offices in various regions worldwide, including a regional office for sales and operations in Latin American and Caribbean markets named LATAM. 


\section{Establishing the regional office LATAM (2013-2016)}

This regional office was established in Mexico City during the summer of 2013 with the following four Danes: two Danes, i.e., a regional director and an export manager, were sent to Mexico from Arla Foods' HQ, and two Danes, a business development manager and a country manager for Mexico, were relocated from a sales office in the Dominican Republic to Mexico. The regional office was gradually staffed with Mexican middle managers with profiles that met the requirements of the local market as follows: knowledge and expertise in international business in Latin America.

A 2013 job advertisement for a Business Development Manager in LATAM, Mexico stated the following:

You will develop and implement together with the LATAM Management team (...) market growth strategies, M\&A projects as well as joint ventures with local partners (...) You will report to the Head of the LATAM office with a dotted line to the central Business Development team based in our headquarters in Denmark. You have a mature project management toolbox that enables you to lead projects independently with limited supervision (...). You are a skilled communicator with an extrovert attitude and an open mind (Arla Foods, 2013).

By the first quarter of 2016, LATAM had recruited seven local managers, all with valuable work experience at international and local firms in the food industry. All managers graduated from bachelor programs at prestigious private business schools in Mexico, and some managers had also studied at the master's level in some specialization programs in Mexico and 
Spain. These individuals were trained in more modern management practices, and most had some international experience.

A Danish manager at LATAM commented the following: 'I think the team here consists of people who are in-between, [people who] can be changed because I have already seen [it] happen...' (BDM.2).

To promote a more robust understanding of the context of our research, we briefly present the following two dimensions, which we have not previously touched upon: 'domestic firms' communication and management practices' and 'home country communication and management practices'. From a macro level, a comparative, cross-cultural perspective, examining paternalistic and participative forms of communication and leadership may enable us to understand the struggles and negotiations within a regional office that may occur due to different collective orientations (cf. Mahadevan, 2017, p. 54).

\section{Paternalistic leadership}

The Global Leadership \& Organizational Behavior Effectiveness (GLOBE) studies (Chhokar et al., 2007; House et al., 2004; Howell et al., 2007), which focus on national cultural values and related qualities in leadership style, claim that managers in Latin America prefer to act as autocratic leaders and practice their unquestioned power in top-down decision-making. Autocratic managers are also concerned with group relationships and developing strong social bonds between superiors and subordinates to build a platform of dependency and mutual loyalty (Martinez, 2003).

According to Davila and Elvira (2012), the apparently contradictory pattern of unquestioned power and care for employees is culturally embedded. These authors explain that a 
paternalistic leadership style emerged in Mexico in privately owned farms (haciendas) where the owner and powerful boss (patrón) provided food and housing to the workers and their families and, in some cases, also medical care and education for the workers' children. In the Mexican colonial context, the patrón emotionally attached the workers to the hacienda; this arrangement ensured that the patrón's need for a stable workforce and the workers' needs for support, protection and care would be met (Dávila and Elvira, 2012). These paternalistic perspectives of leadership are characterized by centralized decision-making in which neither the delegation of responsibility nor empowerment is considered, and the subordinates tend to not question the decisions made (Litrico, 2007).

Dávila and Elvira (2012) coined the concept 'humanistic leadership'; in the Latin American context, these authors describe humanistic leadership as a hybrid of paternalistic leadership in which the boss still cares for the employees and strives to maintain interpersonal harmony as a part of his duty and Western leadership in which the focus is mostly on individual performance. At the individual level, the exercise of humanistic leadership adopts a personcentered view of the relationship between leader and followers and considers the individuals' position and voice within a specific society (Newburry et al., 2014). At the societal level, humanistic leadership suggests that companies play an active role as social institutions and form a part of the social support system to compensate for the lack of tax-funded social services, which are provided by the government in Scandinavian welfare societies.

\section{Participative leadership}

Nordic countries seem to form a country cluster that scores very low in what Hofstede (1980) terms 'power distance' and very high in terms of what the GLOBE study measures as 
'participation in decision-making' (Chhokar et al., 2007). According to the GLOBE study, managers in Scandinavia tend to downplay their authority and prefer more egalitarian practices with the delegation of responsibility to subordinates and the inclusion of employees in ideageneration; this management approach is termed a 'participative leadership style.' This description of preferred practices at the societal macro level can only be used as an initial orientation but cannot predict individual behavior in a specific context. Moreover, what is considered a preferred practice may change over time.

Østergaard (2012) offers a historical frame of reference for understanding preferred values and behavioral patterns as enacted by many businesspeople. He emphasizes that Scandinavian countries have not always been as 'democratic' and 'egalitarian' as they currently are. He suggests that since the late 1920s, the egalitarian practices of the social democratic universal welfare state have profoundly influenced the manners in which many Danes think and act, such as regarding care for the weaker members of a group or community. Since the welfare state offers publicly financed social insurance schemes to citizens not known personally, a high level of interpersonal trust in peers and their needs is essential. The following section presents our methodological approach.

\section{Collection and analysis of the empirical material}

The case study of Arla Foods' regional office, i.e., LATAM, provides a unique setting in which the dimensions of both individual and organizational behavior in an international context become salient. The first author conducted semi-structured face-to-face interviews in Danish, English and Spanish with top managers from Denmark and middle managers from Mexico over a 
period of three years (2014-2017). Several interviews were performed at the HQ in Denmark, although most interviews were conducted at the regional office in Mexico (see Table 1).

Insert Table 1 about here

All interviews were recorded and transcribed. We also reviewed company documents. Our empirical material included participant observations during our company visits; informal conversations in Spanish, Danish and English both face-to-face and via e-mail and telephone; and field notes, in which we reflected upon observations and social interactions. In August 2016, a seminar was held in Mexico City where both authors presented their preliminary findings, listened to spontaneous comments from all LATAM employees, i.e., both Danes and Mexicans, and gathered supplementary information.

In the subsequent analysis of the empirical material, we were attentive to potential communication challenges within the culturally diverse team working in the Mexican sociocultural context, which significantly differs from that at the Scandinavian headquarters. We also focused on the strategies used by the Danes and Mexicans to avoid miscommunication in their daily interactions. Based on our systematically organized empirical material, we also analyzed the following: 1) interview statements regarding the societal context in Denmark and Mexico; 2) interview statements regarding the management practices at Arla Foods and LATAM and the underlying organizational policies; and 3) statements regarding communication between 
the Danes and Mexicans. A theoretically informed understanding of intercultural communication and international business was used in our analysis and interpretation of the empirical material.

Our approach using qualitative research through a case study is driven by two main objectives. First, we have an interest in preserving the semantic richness of the empirical material through the extensive use of quotes from interviews and other sources; these quotes provide readers with insight into how the key actors discuss, interpret and manage their tasks in this specific sociocultural context. Second, we have an interest in describing patterns via categorizations, which could offer a more structured analytical approach to the research issues. The following section presents our findings.

\section{Findings}

At Arla LATAM, there are two groups of relevant actors, i.e., Mexicans and Danes, who are engaged in an ongoing dialogue and recontextualization of certain practices, which evolve based on the following: 1) Arla Foods' strategy and corporate values; 2) Scandinavian communication and management practices; and 3) the colonial legacy and more modern Mexican communication and management practices.

The Danish managers at LATAM have extensive experience with travelling and working as expatriates in Latin America. These managers are also multilingual (Danish, English and Spanish) and, to a certain extent, bicultural (they have lived more than three years in Latin America and the Caribbean).

During the seminar with the two authors at LATAM in 2016, the regional director mocked himself when bringing bottles of water to all LATAM employees before we started 
presenting our preliminary findings. In a comment directed to us, he said, 'you see here [at LATAM] ...the regional director serves the subordinates' (field notes).

Below, we present illustrations of the transformed communication and management practices that emerged through dialogue.

\section{Office layout, communication and language}

The LATAM office is located in an office building in an exclusive area of Mexico City. The common open space at LATAM office has desks separated by small walls only as high as the employees' shoulders. A senior Mexican manager reflected on the evolution of the LATAM office from being 'too Danish' to becoming a 'more Latin office' as follows:

At first, it was complicated because there were more Danes... Danes are quieter than Mexicans... for example [in a typically Mexican workplace], while working, suddenly someone tells a joke [or comments something] and then continues the work. It's not like the Danes who work nonstop from eight to twelve... and then have a 15 minute lunch break (SRC.7).

Another Mexican middle manager said that when he started working at LATAM, he was afraid to type on his computer's keyboard as usual because he thought he was making too much noise. He found that 'the open working space at LATAM was too quiet' (RCM.10); to his relief, when a local administrative officer was hired, the LATAM office started to be more 'Latin,' meaning that there were more spontaneous comments and chit-chat (field notes).

The regional director at LATAM stated that the working language at LATAM is Spanish. Everyone in the regional office is highly proficient in both English and Spanish, and everyone is allowed to select and switch between these languages according to which language fits best in a 
specific situation (participant observations). Spanish is the preferred working language at the LATAM office, and English is the lingua franca in communication with the HQ. The regional director explains the following:

I do not want any employee to speak Danish because it is not fair when there are people who do not speak Danish. So, if you are talking here (in the common facilities) outside your individual office, you have to speak a language that everyone understands. That's why it is Spanish or English because the Mexicans (working in LATAM) also know English. We are adapting a lot, but the values of the office (...) they are Arla Foods' values (RD.1).

Language proficiency might be a critical skill for expatriates to act as boundary spanners. However, cross-cultural communication competencies are also important. This argument is illustrated in the following section.

\section{Direct vs. indirect communication}

Danish managers attempt to be politer and communicate less straightforwardly, especially when evaluating an outcome, to avoid silencing and unintentionally hurting their Mexican colleagues as explained in the following:

I also think the people, we Danes, are very frank, very direct. That can actually be perceived a little bit aggressive in this region [Latin America and the Caribbean] and in Mexico. That's something we have to take care of because we can be very, very outgoing and frank. It's not always positive, or it's not always well accepted by Mexicans when you're so direct. So, we have to wrap in things a little bit and do it more smoothly. So, in 
that way, I think that's something we Danes have to pay attention to because otherwise the Mexicans, they don't say anything. But, you know they get hurt (RD.1).

The above quotation also refers to feedback and 'dialogue,' which is the name of LATAM's biannual formal performance appraisal and feedback session at Arla Foods. As practiced in the Scandinavian context, feedback may imply very direct communication regarding both the good aspects and aspects deserving critique. A Mexican middle manager confirms the interview statement above as follows: '...[here at LATAM, management is] very direct and open' (RCM.8).

Nevertheless, a Mexican middle manager very much appreciates that she is no longer controlled in detail by a superior as she had previously experienced at Mexican firms. At LATAM, her colleagues also listen to her arguments and discuss them openly. The Danish managers at LATAM have also learned that when Mexicans are silent, it does not necessarily mean they agree as follows:

I have observed something that if people don't say anything, it doesn't mean that they agree because in Denmark if we are discussing, I'll probably say, 'Okay yeah, but I don't agree with you.' It doesn't happen in Mexico so often. In that way, you have to say, 'But, what do you think about this? Do you agree?' 'No, I don't.' 'Why?' You have to ask a lot of times to make sure that the people understand and agree with what you suggest because, otherwise, you could go out of the meeting and simply expect, 'Okay guys, we had a great meeting, and we all agreed' - 'No, we did not' (SMD.11).

The Danish expatriate managers consciously practice very direct communication in situations in which they have found that Mexicans tend to avoid communicating directly regarding potential delays or alternative plans as follows: 
For example, if we have a meeting tomorrow, I normally call the day before and say, 'Santiago, remember we have a meeting tomorrow at 2:00 pm.?' I have a lot of control through calls and through emails. If they don't reply, I just call them again. That's something I use a lot of time on. Because if not, it could be that the Mexican has seen my email, but if he doesn't like the response he has to make, sometimes, it's easier to not reply. That is something I have learned (SMR.11).

In an interview in 2014, the Danish regional director emphasizes that his practices at LATAM are not necessarily based on so-called Scandinavian values and management ideas as coined in the description of 'participative leadership' but are based on the following corporate values: lead, sense and create; these values are the preferred behaviors developed by Arla Foods and include trust, flexibility, work/life balance, an informal community of peers, being proactive and taking initiative (cf. also an Arla Foods' HQ manager's presentation in November 2014). These corporate values promoted at LATAM are discussed further below.

\section{Trust, flexibility and work/life balance}

Upon exiting the elevator to the main entrance of the LATAM office, an opposite entrance door leads to a firm headed by a Mexican manager. LATAM's regional director stated that every morning, the employees of the other firm wait in front of the entrance until their boss unlocks the door at 9 a.m., and they all leave the office at a certain point when the boss decides to go home, which is normally at approximately $6 \mathrm{pm}$. The Danish director of the regional office uses this story to contrast his leadership style with a more flexible method of address time and respecting the differences in the employees' life situations as follows: I can go into the office at 
seven, and I can leave at four. I can be with my family, or if one day I want to go in at nine o'clock and leave at seven o'clock, I can do it late, too (RD.1).

In relation to Arla Foods' character Sense, the regional director also emphasizes that he trusts his employees; therefore, he accepts flexi-schedules as long as the employees perform their jobs and deliver as expected. Accordingly, he provided all staff members with a key to the entrance door such that they can start working according to their individual plans and family obligations.

If they [local employees] want to work on Mexican schedules, they can. That is, they enter the office from 8:30 a.m. to 9:00 a.m., work until noon and have two hours of lunch if they want. We said you can select whatever you want. The most important thing for us is that you reach your goals (SD.1).

An alternative work-schedule, labeled an 'intense work schedule,' has been introduced by the regional director, who suggests that employees work without major breaks from 7:00 to 14:00. Thus, the employees can 1) avoid traffic jams and 2) be at home in time for dinner with their families at 18:00 [normally in Denmark, family dinner takes place at 18:00, whereas in Mexico, it is at approximately 20:00], thereby experiencing a better work-life balance. The 'intense work schedule' is not a compulsory practice as flexibility is presented as a core value at LATAM. The Danish regional director commented that 'if the Mexicans want to keep their onehour lunch break and leave the office at 17:00 or 18:00, it is just fine with me.' However, some Mexican managers who do not want to follow the proposed schedule argue that 'At 12:00, I am not hungry... and I cannot eat at that time in 15 minutes!' (SR.7). 
Another management idea that the regional director attempted to develop is a self-driving team as follows: 'We also have to make it visible that you [the employee] should not just sit and wait for the boss to take initiative. You have to be active yourself.'

In relation to Arla Foods' character associated with creation, a Mexican manager comments about her experiences with the shift in perspective regarding hierarchy and authority since she was recruited to the LATAM office and the management ideal of empowerment with delegation of responsibility to make decisions that seem to be inherent in Arla Foods' method of managing people as follows:

'...it's like I totally changed my pace of work/life. It has also changed hierarchies. Here in Mexico, you know, there are a lot of hierarchies... but not in here [LATAM]. There is much empowerment to the people such that you can make decisions, and that is also very good' (SRC.7).

\section{Informal community of peers}

The regional director considers the staff of LATAM a community of peers and attempts to 'break down hierarchies and create followership' as is preached at leadership seminars at Arla Foods' HQ. A Mexican employee describes the experience of working as a team independent of the Danish managers' instructions and daily follow-up as follows:

I believe it is teamwork; they (top management) set the deadline... It's very different working in Europe and working in Mexico; we have to keep remaining all the time on our request to our local partners... perhaps in Mexico, firms that work with us feel a bit pressed because we have to teach them how we [would like] to work with them (SD.1). 
To build a 'friendly' work environment at LATAM, the regional director has taken initiative by introducing a weekly breakfast based on inspiration from a workshop about teambuilding with other Arla Foods directors of regional offices. Every Wednesday at 9:00 am, all employees at LATAM sit together around a table and eat dark bread with butter and slices of yellow cheese as many Danes would do. It is an occasion used to discuss private issues, such as life outside the workplace with family and friends, and comment about daily news or current local sports events. As a participant in and observer of this breakfast ritual, one author was particularly struck by the fact that it is a purely Danish breakfast ritual with Arla Foods' dairy products introduced in a context in which Mexicans would normally gather at that time of the day and eat tacos with minced meat, vegetables and perhaps some grated and melted cheese and a hot chili sauce.

The regional director summarizes his reflections of the management style he attempts to practice, which, to a great extent, has been appreciated by the Mexican staff as follows: I think we have implemented a management style in the very Scandinavian office, but Ifeel my Mexicans like it (...) We are a company from Europe, and we bring the values of Arla Foods, and the values of Arla are like this.

\section{Mexican employees' expectations of humanistic management}

The interviews with the Mexican middle managers indicate that they were attracted by and in their daily work appreciate Arla Foods' way of managing people. Nevertheless, a female Mexican staff member at LATAM voices her expectations for the Danish regional director, which mirror the aforementioned description of paternalistic leadership, as follows: 'The leader, he is the one to guide us and show in which direction we are going to move...' 
The interviews revealed caring behaviors in the LATAM context combined with a flexible attitude regarding where and when work is performed as long as the tasks are accomplished. For example, a female Mexican export assistant states that she felt serious doubt about how the LATAM office would respond when she broke her ankle. She was relieved when she determined that Arla Foods not only 'cares for the environment' but indeed also 'cares in every step' for their employees as the company claims on the corporate website as follows:

I do exercises. I fell from a rail, and well, I arrived with a cast on my foot in the lounge outside the LATAM office. (...) I said, 'How is this managed in Arla?' I didn't know. I had worked ... six months in the company, so I said, 'How's this?' (...) They asked me 'What happened to you?' and I told them and got all the support (I needed): 'Don't worry.' You know, the home office with the laptops and the IT system that Arla uses is very efficient; I mean, you can work wherever you want and at any time you want (EA.5).

A Mexican manager states that he is very satisfied with working at LATAM, but he also raises concerns regarding non-monetary compensation as follows:

...It's just like I'm in paradise, still [laughs]. But, I think the issue of benefits is super important! [What kind of benefits?]... For example, a savings fund, [what else?]...coupons to buy groceries. We have health insurance, but obviously, I had a better one before [in the previous firm]; for instance, I could go to the doctor for check-ups. I had discount at the gym... yesterday, I paid the gym, and I said, I do not have that benefit anymore! You will receive these benefits in a big company (RCM.8).

Other Mexican staff members voiced concerns regarding compensation as a 'trade-off' as follows:

When it comes to benefits, they are not the same. Nestle had better ones, and there are 
other companies in Mexico City with better ones, but it was a trade-off. (...) My priorities were: first, a challenging job, second, a good work-life balance and third, a good salary (SRC.8).

In the following section, we discuss the empirical findings and present our model of the recontextualization of communication and management practices, thereby highlighting our research contributions.

\section{Discussion}

In this research, we propose recontextualization (Brannen, 2004) as a complementary theoretical perspective to discuss the I-R framework (Roth and Morrison, 1990) with reference to how foreign subsidiaries of MNCs regard preferred practices from $\mathrm{HQ}$. We developed a case study of a regional office in Mexico of a Danish MNC (Arla Foods). Our study addresses the following two questions: 1 . Are Scandinavian communication and management practices adapted to local traditions and needs through dialogue between Danish and Mexican managers? and 2. Are the corporate values of Scandinavian MNCs adapted to the local context?

We showed that Mexican employees implicitly translate and reinterpret some practices rooted in Scandinavian communication and management ideas and Arla Foods' corporate values via their local cultural framework. The corporate values are framed by Arla Foods as the MNC's "Character" as follows: Lead, Sense, and Create. All LATAM employees were trained in these values through Arla Foods' e-learning platform. Thus, Arla Foods' Character appears to be reflected in the regional office; there is a high degree of trust in the subordinates and a low degree of formal control, which are highly appreciated by the Mexican middle managers. Many local employees at LATAM explicitly state that one reason they applied for a job at a 
Scandinavian MNC was to move away from close supervision, which is embedded in the paternalistic leadership style still prevalent in many Mexican family owned companies (Dávila and Elvira, 2012; Martinez, 2003).

Regarding our research questions, dialogue and recontextualization do not always occur. We showed that the Danish expatriates at LATAM sometimes impose Arla Foods' communication and management practices rather than act as boundary spanners to give sense to Arla Foods' corporate values even though these values are rooted in a Scandinavian context. We find that the regional director attempted to gradually transform the current Mexican practices at LATAM by introducing a Danish breakfast with the intention to create a more "friendly work environment." However, this practice was not at all recontextualized. Nevertheless, the Mexican employees join the unusual breakfast meal perhaps because they realize it is an opportunity to gradually develop "an informal community of peers," which is an Arla Foods corporate value that they enjoy since they highly appreciate Arla Foods' more egalitarian and informal way of communicating and collaborating in which employees can ask questions and raise concerns regardless of their rank in the company hierarchy.

Another non-transformed managerial initiative that mirrors a Scandinavian work practice is the "intense work schedule" in which employees work from 7 am-2 pm with only short breaks during the day. The regional director frames this schedule as a suggestion rather than an order, and this schedule is supported by the argument that it enables a better "work-life balance" and reflects employees' best capabilities (Arla Foods, 2019), which is another strong corporate value of Arla Foods. However, according to the interviews, "work-life balance" has also persuaded many Mexican middle managers to apply for a job at the company despite the company being unknown to them. The fact that some Mexicans nevertheless maintain their preference for a long 
lunch break at $3 \mathrm{pm}$, consequently leaving the office late and having dinner at home at $8 \mathrm{pm}$, only illustrates the argument proposed by d'Iribarne and Henry (2007) and Yousfi (2014) that expatriate managers must acknowledge the persistence and cultural continuity of the local way of organizing and regulating social life.

There are some notable similarities between our case study and that reported by d'Iribarne and Henry (2007) although these authors examined the production site of a French MNC (Danone)'s Mexican subsidiary, while our case study examines a regional sales office. Both studies demonstrated that Mexican employees welcomed some changes introduced by European expatriate managers, such as the shift in superior-subordinate relationships from distant to less hierarchical. This change highly motivated the local middle managers, who felt they were more able to contribute to decision-making processes. The employees also felt trusted when specific tasks were delegated to them and empowered that their managers encouraged them to work without undue control and supervision. Moreover, the employees felt that this change helped them grow and develop new skills and competencies; they were even more confident in asking their colleagues for help or advice.

In contrast to previous research investigating practices that travel (d'Iribarne, 2002; Yousfi, 2014), our empirical findings advance the existing knowledge regarding "foreign locals" (Caprar, 2011). The Mexican middle managers at LATAM are well educated and attended highranked universities and business schools. These managers are typically familiar with American literature concerning international business issues and have international experience from working in Mexican and foreign MNCs. Therefore, these Mexican middle managers do not necessarily expect to find traditional Mexican communication and management practices in the regional office of a Scandinavian MNC. In contrast, as "foreign locals" (Caprar, 2011), these 
managers aspire to a more egalitarian workplace culture and better work-life balance. They have deliberately chosen to work at LATAM rather than in a more traditionally led Mexican company because they wish to be more involved in decision-making and have more individual responsibility.

According to d'Iribarne (2002), Mexican workers at Danone's production facilities developed a strong sense of belonging to the company and gradually began to perceive their colleagues as members of a tightly knit family. They were also strongly motivated by the attractive features offered by the French MNC, such as a higher salary than other local workplaces and high job security. They readily adapted to more caring behavior than is traditional with Mexican bosses, which, in many aspects, is similar to the help and protection that a colonial patrón offers colonized local workers for the benefit of his own enterprise.

Compared with Danone, the Mexican middle managers' expectations of a high salary and monetary compensation packages when working for a foreign MNC were not met at the Arla LATAM office. Shimoni and Bergmann (2006) described how a Swedish MNC introduced a consensual decision-making system to its Mexican subsidiary that was similar to that used at HQ but avoided introducing the expensive wage system offered to the employees at the HQ. In our study in LATAM, we found a similar paradox. Mexican employees were introduced to the Scandinavian egalitarian ways of communicating and collaborating, but their expectations regarding compensation systems were confronted with an HR policy developed at the MNC's HQ, which exists in a Scandinavian welfare state. In Denmark, programs, such as free access to education and health care for children and adults, are reimbursed through taxes, and thus, these issues are typically not negotiated with an employer. Following their example, the regional director of Arla LATAM explains that there is nothing to negotiate because as an expatriate 
manager, he is expected to only comply with the Scandinavian MNC's global HRM standardization (Perlmutter, 1969; Roth and Morrison, 1990) and not question their universal applicability.

Based on this case analysis, we further developed the theoretical perspective into a model that conceptualizes the recontextualization processes that we sought to study (see Figure 1).

Figure 1 about here

Figure 1 demonstrates the purpose of dialogue in the potential recontextualization of an MNC's communication and management practices. According to the model, local employees and expatriates in a foreign subsidiary engage in their daily work in a type of a dialogue regarding transformation and the cultural continuity of current communication and management practices. This process implicitly involves the actual political and socio-economic contexts and the cultural legacy in the host country and in the MNC's home country. Gender and age are features to consider when interpreting our findings. Table 1 shows that male local managers are mid-career types (40s), whereas the female local managers are younger (30s). These differences could be a line for future research in relation to millennials ( $\mathrm{Ng}$, Lyons and Schweitzer, 2017) since in an emerging market, millennials may present particular challenges for MNCs that prefer to adhere to global HR standards regardless of the local job market and local employees' needs. These gender and age aspects along with MNCs' strategies and values may impact the balance between global integration and local responsiveness (i.e., I-R) (Roth and Morrison, 1990). 
Our proposed model provides different managerial implications with which to discuss the I-R framework. These implications are presented below.

\section{Managerial relevance}

Our case study offers insight of relevance to practitioners. This study highlights the importance of an MNC considering the skills and competencies of expatriate managers when staffing a new regional office as a part of a company's internationalization strategy. This study demonstrates the importance of selecting expatriate managers with both bilingual and bicultural profiles and international experience from the region to head a new regional office. Expatriates' high proficiency in the local language is important to give sense to the MNC's values in the host country and manage negotiation and recontextualization processes (Peltokorpi and Vaara, 2012). A deep understanding of communication processes based on the host country's current context and the legacy of the socioeconomic conditions that frame the work in a regional office could assist in recruiting, motivating and retaining local managers. Then, these local managers could similarly act as boundary spanners across national and organizational divides in the development of new sustainable communication and management practices.

Our case study might help expatriates recognize that the successful recontextualization of communication and management practices can become a source of organizational learning and, in turn, a competitive advantage. Unsuccessful recontextualization can have a negative impact that takes various forms; for example, a company might face severe challenges in attracting and retaining local people with the required knowledge and skills if they do not respect the local frameworks of meaning and the socioeconomic conditions under which their local employees live and work. 
Our case also demonstrates to practitioners that there are still limits to how expatriate managers can maneuver if there is limited cultural sensitivity and understanding of other socioeconomic conditions at the headquarter level. Regardless of how well travelled expatriate managers are, how high their proficiency in the local language is or how well embedded they are in the host country's business context, their endeavors will be blocked if the HQ of the MNC insists on global standards when local adaptations are needed.

\section{Concluding remarks}

IB researchers have problematized the lack of the recontextualization of communication and management processes from HQ to subsidiaries (e.g., Brannen, 2004; Gertsen and Zølner, 2012; Moore, 2015) and shown that values and practices are not only seamlessly 'transmitted' and 'transferred'. Our theoretical model visualizes the complexity of recontextualization processes.

Our case study offers an empirical contribution to the intercultural communication and international business literature with an emphasis on a contextualized analysis and understanding of social interactions in a Latin American regional office of a Scandinavian MNC where local meaning systems affect the concepts and practices that the MNC aims to promulgate to its subsidiaries. We illustrate how certain communication and management practices are successfully transformed through dialogue and reflexivity among the relevant Danish and Mexican organizational actors, whereas other practices rooted in either Mexican or Scandinavian business traditions remain untouched and, thus, persist and represent a type of continuity of a cultural legacy. 


\section{References}

Ansari, S.M., Fiss, P.C. and Zajac, E.J. (2014), "Made to fit: how practices vary as they diffuse", Academy of Management Review, Vol. 35 No. 1, pp. 67-92.

Arla Foods (2013), Business Development Manager-LATAM, Interna Documents from Arla Foods, Denmark.

Arla Foods (2014), Presentation of Arla Foods, Internal Documents from Arla Foods, Denmark. Arla Foods (2016), Arla Foods corporate strategy-good growth 2020. Retrieved from http://www.arla.com/company/strategy/strategy-2020/overview/ (accessed 28 November 2016).

Arla Foods (2018), Consolidated Annual Report 2018, transforming for the future. Retrived from https://www.arla.com/4927e1/contentassets/d968a7fbbad24880a14ada9e65e91f44/arla_c onsolidated_annual_report_2018.pdf (accessed 8 July 2019)

Arla Foods (2019), "Our Values", available at: https://www.arla.com/company/strategy/values/ (accessed 20 April 2019).

Bartlett, C.A. and Ghoshal, S. (1989), Managing across Borders: The Transnational Solution, Harvard Business School Press, Boston.

Brannen, M.Y. (2004), "When mickey loses face: recontextualization, semantic fit, and the semiotics of foreignness", The Academy of Management Review, Vol. 29 No. 4, pp. 593616.

Caprar, D.V. (2011), "Foreign locals: a cautionary tale on the culture of MNC local employees", Journal of International Business Studies, Vol. 42 No. 5, pp. 608-628. 
Chhokar, J.S., Brodbeck, F.C. and House, R.J. (2007), Culture and Leadership across the World: A GLOBE Report of in-Depth Studies of the Cultures of 25 Countries, Lawrence Erlbaum Associates, Mahwah, NJ.

Czarniawska, B. and Sevón, G. (1996), "Introduction", in Czarniawska, B. and Sevón, G. (Eds.), Translating Organizational Change, Walter de Gruyter, New York, NY, pp. 1-12.

Czarniawska, B. and Sevón, G. (2005), Global Ideas: How Ideas, Objects and Practices Travel in the Global Economy, Liber, Lund, Copenhagen.

d'Iribarne, P. (2002), "Motivating workers in emerging countries: universal tools and local adaptations", Journal of Organizational Behavior, Vol. 23 No. 3, pp. 243-256.

d'Iribarne, P. (2012), Managing Corporate Values in Diverse National Cultures: The Challenge of Differences, Routledge, New York, NY.

d'Iribarne, P. and Henry, A. (2007), Successful Companies in the Developing World: Managing in Synergy with Cultures, Agence Française de Développement, Paris, France.

Davila, A. and Elvira, M.M. (2012), "Humanistic leadership: lessons from Latin America", Journal of World Business, Vol. 47 No. 4, pp. 548-554.

Frenkel, M. (2008), "The multinational corporation as a third space: rethinking international management discourse on knowledge transfer through Homi Bhabha", Academy of Management Review, Vol. 33 No. 4, pp. 924-942.

Gertsen, M.C. and Zølner, M. (2012), "Recontextualization of the corporate values of a Danish MNC in a subsidiary in Bangalore", Group \& Organization Management, Vol. 37 No. 1, pp. 101-132.

Gioia, D.A. and Chittipeddi, K. (1991), "Sensemaking and sensegiving in strategic change initiation", Strategic Management Journal, Vol. 12 No. 6, pp. 433-448. 
Hofstede, G. (1980), Culture's Consequences: International Differences in Work-Related Values, SAGE Publications, Beverly Hills, CA.

House, R.J., Hanges, P.J., Javidan, M., Dorfman, P.W. and Gupta, V. (2004), Culture, Leadership and Organizations: The GLOBE Study of 62 Societies, SAGE Publications, London, UK.

Howell, J.P., DelaCerda, J., Martínez, S.M., Prieto, L., Bautista, J.A., Ortiz, J., Dorfman, P. and Méndez, M.J. (2007), "Leadership and culture in Mexico", Journal of World Business, Vol. 42 No. 4, pp. 449-462.

Kogut, B. and Zander, U. (2003), "Knowledge of the firm and the evolutionary theory of the multinational corporation", Journal of International Business Studies, Vol. 34, pp. 516529.

Kostova, T. and Roth, K. (2002), "Adoption of an organizational practice by subsidiaries of multinational corporations: institutional and relational effects", Academy of Management Journal, Vol. 45 No. 1, pp. 215-233.

Lenartowicz, T. and Johnson, J.P. (2002), "Comparing managerial values in twelve Latin American countries: an exploration study", Management International Review, Vol. 42 No. 3, pp. 279-307.

Liker, J.K., Fruin, W.M. and Adler, P.S. (1999), Remade in America: Transplanting and Transforming Japanese Management Systems, Oxford University Press, New York, NY.

Litrico, J.-B. (2007), "Beyond paternalism: cross-cultural perspectives on the functioning of a Mexican production plant", Journal of Business Ethics, Vol. 73 No. 1, pp. 53-63.

Mahadevan, J. (2017), A Very Short, Fairly Interesting and Reasonably Cheap Book About Cross-Cultural Management, Sage, Los Angeles, CA. 
Marketing 91. (2018), Dairy Companies - Top 20 Dairy Companies Explain. Retrieved from 8, 2019, from https://www.marketing91.com/top-dairy-companies/ (accessed 8 July 2019).

Martinez, P.G. (2003), "Paternalism as a positive form of leader-subordinate exchange: evidence from Mexico", Management Research, Vol. 1 No. 3, pp. 227-242.

Meyer, K. E. (2002), "Management Challenges in Privatization Acquisitions in Transition Economies”, Journal of World Business, Vol. 37, No. 4, pp. 266-76.

Moore, F. (2015), "An unsuitable job for a woman: a 'native category' approach to gender, diversity and cross-cultural management", The International Journal of Human Resource Management, Vol. 26 No. 2, pp. 216-230.

Nardon, L., Steers, R.M. and Sanchez-Runde, C.J. (2011), "Seeking common ground: strategies for enhancing multicultural communication", Organizational Dynamics, Vol. 40 No. 2, pp. 85-95.

Newburry, W., Gardberg, N.A. and Sanchez, J.I. (2014), "Employer attractiveness in Latin America: the association among foreignness, internationalization and talent recruitment", Journal of International Management, Vol. 20 No. 3, pp. 327-344.

Ng, E. S., Lyons, S. T., and Schweitzer, L. (2017), "Millennials in Canada: Young workers in a challenging labour market”, in E. Parry and J. McCarthy (Eds.), The palgrave handbook of age diversity and work. London: Palgrave Macmillan UK, pp. 325-344.

Østergaard, U. (2012), "Danish national identity: a historical account", in Gertsen, M.C., Søderberg, A.M. and Zølner, M. (Eds.), Global Collaboration: Intercultural Experiences and Learning, Palgrave Macmillan, Basingstoke, UK, pp. 37-55. 
Peltokorpi, V. and Vaara, E. (2012), "Language policies and practices in wholly owned foreign subsidiaries: a recontextualization perspective", Journal of International Business Studies, Vol. 43, pp. 808-833.

Perlmutter, H.V. (1969), "The tortuous evolution of the multinational corporation", Columbia Journal of World Business, Vol. 4 No. 1, pp. 9-18.

Prahalad, C.K. and Doz, Y.L. (1987), The Multinational Mission: Balancing Local Demands and Global Vision, The Free Press, New York.

Rabobank (2018), Global Dairy Top 20. Retrieved from https://research.rabobank.com/far/en/sectors/dairy/Dairy-top-20-2018.html (accessed 8 July 2019).

Roth, K. and Morrison, A.J. (1990), "An empirical analysis of the integration-responsiveness framework in global industries", Journal of International Business Studies, Vol. 21 No. 4, pp. 541-564.

Schmid, S. (2018), "Strategies of internationalization: an overview", in Schmid, S. (Ed.) Internationalization of Business, MIR Series in International Business, Springer, Cham, pp. 1-25.

Shimoni, B. and Bergmann, H. (2006), "Managing in a changing World: from multiculturalism to hybridization — the production of hybrid management cultures in Israel, Thailand, and Mexico", Academy of Management Perspectives, Vol. 20 No. 3, pp. 76-89.

Søderberg, A.M. (2015), "Recontextualising a strategic concept within a globalising company: a case study on Carlsberg's 'winning behaviours' strategy", International Journal of Human Resource Management, Vol. 26, pp. 231-257. 
Yousfi, H. (2014), "Rethinking hybridity in postcolonial contexts: what changes and what persists? The Tunisian case of Poulina's managers", Organization Studies, Vol. 35 No. 3 , pp. 393-421. 
Table 1: Sample - information about the interviewees.

\begin{tabular}{|c|c|c|c|c|c|c|}
\hline $\begin{array}{l}\text { Employee/ } \\
\text { Position }\end{array}$ & $\begin{array}{c}\text { Age (in } \\
\text { 2017) }\end{array}$ & Gender & Nationality & $\begin{array}{l}\text { Formal } \\
\text { Interview } \\
\text { \& } \\
\text { Language: } \\
\text { Spanish } \\
\text { (SP), } \\
\text { Danish } \\
\text { (DK) and } \\
\text { English } \\
\text { (ENG) }\end{array}$ & $\begin{array}{l}\text { Informal } \\
\text { Conversation } \\
\text { \& Language: } \\
\text { Spanish (SP), } \\
\text { Danish (DK) } \\
\text { and English } \\
\text { (ENG) }\end{array}$ & Locations \\
\hline $\begin{array}{l}\text { (1) RD.1: } \\
\text { Regional } \\
\text { Director } \\
\text { LATAM }\end{array}$ & 37 & Male & Danish & $\begin{array}{lr}(1) & 2014 \\
(\mathrm{SP}), & (2) \\
2015 & (\mathrm{SP}), \\
(3) & 2016 \\
(\mathrm{ENG}) & \\
\end{array}$ & $\begin{array}{l}\text { (1) } 2013 \text { (DK), } \\
\text { (2) } 2014 \text { (SP), } \\
\text { (3) } 2015 \text { (SP), } \\
\text { (4) } 2016 \text { (SP) }\end{array}$ & $\begin{array}{l}\text { Copenhagen, } \\
\text { Mexico City }\end{array}$ \\
\hline $\begin{array}{l}\text { (2) BDM.2: } \\
\text { Business } \\
\text { Development } \\
\text { Manager }\end{array}$ & 41 & Female & Danish & $\begin{array}{lr}(4) & 2014 \\
(\mathrm{SP}), & (5) \\
2015 & (\mathrm{SP}), \\
(6) & 2016 \\
(\mathrm{SP}) & \\
\end{array}$ & $\begin{array}{l}\text { (5) } 2014 \text { (SP), } \\
\text { (6) } 2015 \text { (SP), } \\
\text { (7) } 2016 \text { (SP) }\end{array}$ & $\begin{array}{l}\text { Copenhagen, } \\
\text { Mexico City }\end{array}$ \\
\hline $\begin{array}{l}\text { (3) AA.3: } \\
\text { Administrative } \\
\text { Assistant }\end{array}$ & 30 & Female & Colombian & $\begin{array}{ll}(7) & 2016 \\
\text { (SP) } & \end{array}$ & (8) 2016 (SP) & Mexico City \\
\hline $\begin{array}{l}\text { (4) SM.4: } \\
\text { Senior } \\
\text { Manager }\end{array}$ & 37 & Male & Mexican & $\begin{array}{ll}(8) & 2016 \\
(\mathrm{SP}) & \end{array}$ & (9) 2016 (SP) & Mexico City \\
\hline $\begin{array}{l}\text { (5) EA.5: } \\
\text { Export } \\
\text { Assistant }\end{array}$ & 41 & Female & Mexican & $\begin{array}{ll}(9) & 2016 \\
\text { (SP) } & \end{array}$ & (10) 2016 (SP) & Mexico City \\
\hline $\begin{array}{l}\text { (6) EM.6: } \\
\text { Export } \\
\text { Manager }\end{array}$ & 43 & Male & Mexican & $\begin{array}{l}(10) \quad 2015 \\
\text { (SP), } \quad(11) \\
2016 \text { (SP) }\end{array}$ & $\begin{array}{lr}(11) & 2015 \\
(\mathrm{SP}), & (12) \\
2016 \text { (SP) } & \end{array}$ & $\begin{array}{l}\text { Mexico City, } \\
2016 \text { (Phone } \\
\text { interview) }\end{array}$ \\
\hline $\begin{array}{l}\text { (7) SRC.7: } \\
\text { Senior } \\
\text { Regional } \\
\text { Category } \\
\text { Manager }\end{array}$ & 37 & Male & Mexican & $\begin{array}{ll}(12) & 2016 \\
\text { (SP) } & \end{array}$ & N/A & Mexico City \\
\hline
\end{tabular}


Table 1: Sample - information about the interviewees. (Continue)

\begin{tabular}{|c|c|c|c|c|c|c|}
\hline $\begin{array}{l}\text { Employee/ } \\
\text { Position }\end{array}$ & $\begin{array}{l}\text { Age } \\
\text { (in } \\
\text { 2017) }\end{array}$ & Gender & Nationality & $\begin{array}{l}\text { Formal } \\
\text { Interview \& } \\
\text { Language: } \\
\text { Spanish } \\
\text { (SP), Danish } \\
\text { (DK) and } \\
\text { English } \\
\text { (ENG) }\end{array}$ & $\begin{array}{l}\text { Informal } \\
\text { Conversation } \\
\text { \& Language: } \\
\text { Spanish (SP), } \\
\text { Danish (DK) } \\
\text { and English } \\
\text { (ENG) }\end{array}$ & Locations \\
\hline $\begin{array}{l}\text { (8) RCM.8: } \\
\text { Regional } \\
\text { Category } \\
\text { Manager }\end{array}$ & 35 & Female & Mexican & $\begin{array}{l}(13) \\
2016(\mathrm{SP})\end{array}$ & N/A & Mexico City \\
\hline $\begin{array}{l}\text { (9) RCM.9: } \\
\text { Regional } \\
\text { Category } \\
\text { Manager }\end{array}$ & 43 & Male & Mexican & $\begin{array}{l}\text { (14) } 2016 \\
\text { (SP) }\end{array}$ & N/A & Mexico City \\
\hline $\begin{array}{l}\text { (10) HBD.10: } \\
\text { Head of } \\
\text { Business } \\
\text { Development }\end{array}$ & 45 & Male & Danish & $\begin{array}{l}\text { (15) } 2014 \\
\text { (ENG), (16) } \\
2015 \text { (ENG) }\end{array}$ & $\begin{array}{l}\text { (13) } 2014 \\
\text { (ENG), (14) } \\
2015 \text { (DK) }\end{array}$ & Copenhagen \\
\hline $\begin{array}{l}\text { (11) SMR.11: } \\
\text { Sales } \\
\text { Manager } \\
\text { Regional }\end{array}$ & 45 & Male & Danish & $\begin{array}{l}\text { (17) } 2014 \\
\text { (ENG), (18) } \\
2015 \text { (ENG) }\end{array}$ & (15) 2014 (DK) & $\begin{array}{l}\text { Copenhagen, } \\
\text { Mexico City }\end{array}$ \\
\hline $\begin{array}{l}\text { (12) SC.12: } \\
\text { Sales-Central } \\
\text { America }\end{array}$ & 37 & Male & Danish & $\begin{array}{l}\text { (19) } 2014 \\
\text { (SP) }\end{array}$ & N/A & Mexico City \\
\hline $\begin{array}{l}\text { (13) HRA.13: } \\
\text { HR Assistant }\end{array}$ & 30 & Female & Danish & N/A & $\begin{array}{l}\text { (16) } 2014 \\
\text { (ENG) }\end{array}$ & Copenhagen \\
\hline
\end{tabular}


Figure 1: Recontextualization of Communication and Management Practices in a Foreign Regional Office of an MNC

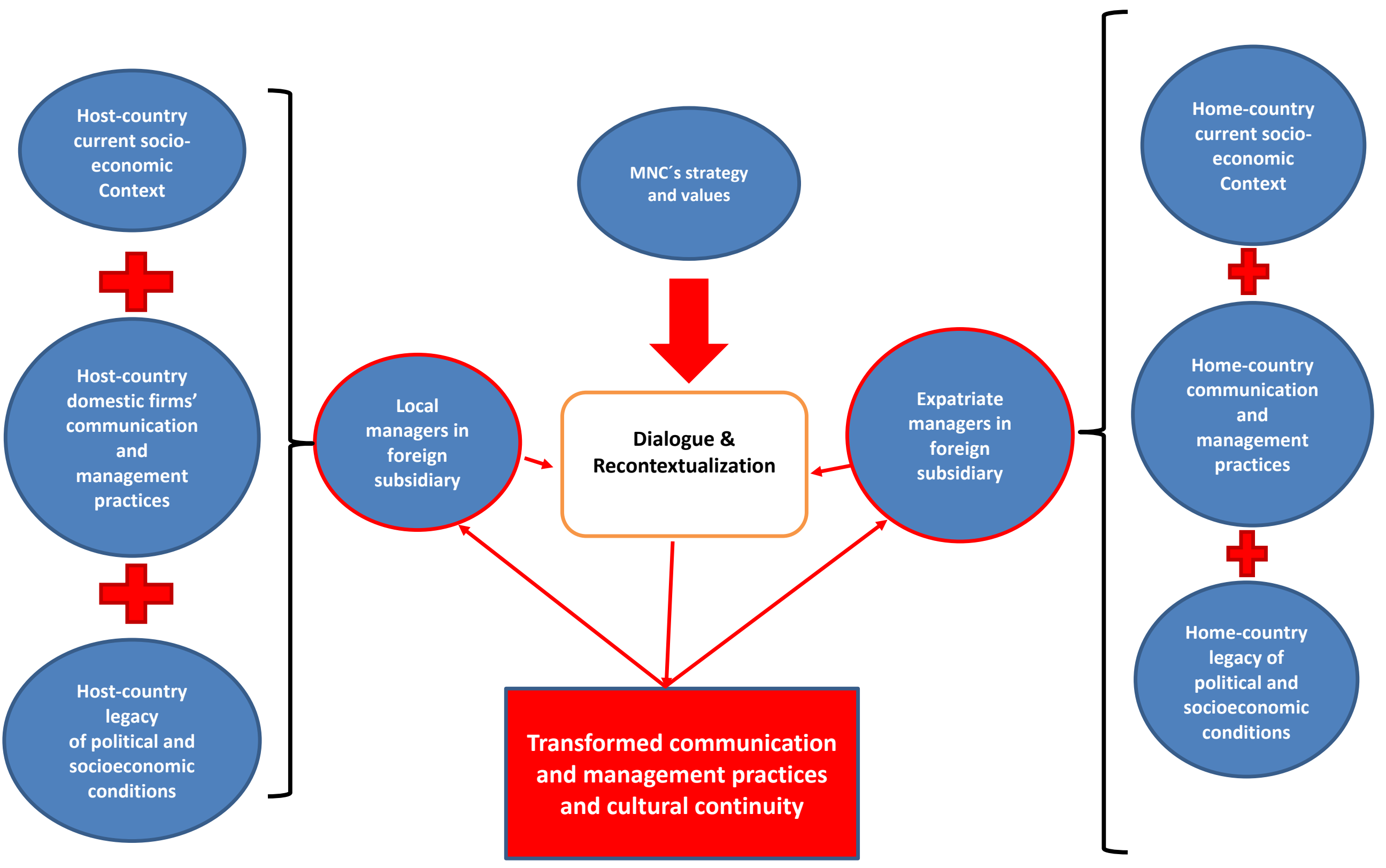

